\title{
МОДЕСТ МУСОРГСКИЙ И МИХАИЛ БУЛГАКОВ: НЕОЖИДАННЫЕ ПАРАЛЛЕЛИ
}

Исследовательская проблема драматургической функџии музыкальных ассоџиаџий в творческом наследии Михаила Булгакова отнюдь не обделена в наши дни вниманием ни музыковедов, ни филологов. Скорее следует утверждать прямо противоположное, в подтверждение чего можно привести достаточное количество весомых и объективных аргументов, не говоря уже о внушительном списке научной литературы.

Не так уж много найдется в истории российской культуры сочинений нарративных и театральных жанров, где џитаты ключевых фраз из оперных арий и популярных песен, сюжетно важные упоминания о танџах и маршах, о различных формах музиџирования и сопутствуюших им бытовых обычаях играли бы столь сушественную роль и занимали столь значительное место в многослойном развертывании фабулы, как у названного выше автора. Равным образом, обшее число собственно научных исследований, как и других самого разного рода публикаџий, посвященных данной проблематике, тоже весьма велико. Особенно принимая во внимание тот исторически очень короткий - чуть более четверти века, начиная с 1987 года отрезок времени, когда искусствоведческое сообџество стало постепенно получать, наконеџ, относительно свободный доступ к художественным текстам писателя и к архивным материалам его творческой биографии.

В этих многоплановых исследованиях и публикаџиях даже самый нижний, информаџионный слой содержания представляет памяти читателей имена как всемирно знаменитых, так и не столь уж известных композиторов от Верди до Глиәра, от Чайковского до Вильбоа. И далее... Рубинштейна, Кюи,

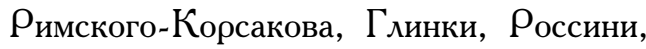
Мейербера, Вагнера, Листа, Бизе, Глюка, Берлиоза (конечно здесь - автора «Ф Оантастической симфонии»).

Только фамилии Мусоргского среди композиторов тут не встречается.

Мы не находим ее ни в булгаковских романах, ни в рассказах, ни в пьесах, ни в мемуарах, ни в научных статьях, ни в монографиях. Подобное обстоятельство никоим образом не может быть отнесено к чистой случайности, ибо этому явно противоречит фактор редкой полноты отображения писателем панорамы оперной и концертной жизни Киева второго десятилетия XX века.

Возможно ли хоть чем-либо объяснить столь значительный пробел?

Неужто Булгаков не знал музыки «Бориса Годунова» и «Хованшины»?

Не явился ли причиной умолчания скрытый антагонизм двух гениев?

Ответы на вопросы будут неожиданными, причем они потребуют рассмотрения 
проблематики не только с постепенным углублением в текстовые материалы романа «Белая гвардия», но и в аспекте воздействия приемов музыковедческого анализа на аналитический аппарат филологических наук, а также в плоскостях религиозно-мировоззренческой и социально-исторической. Такое соединение неизбежно в те критические для государств и народов периоды, когда на передний план выходят все приметы смутного времени и трагического раскола - как в сознании разных слоев общества, так и в умах и душах конкретных героев романа или оперы.

...Научное приближение к решению вопросов о значении музыкальных аллюзий в текстах булгаковских произведений началось почти одновременно в двух семантических сферах: как плодотворное встречное движение от источниковедения к эстетическим выводам и в обратном направлении.

Завершение 1980-х ознаменовалось изданием сборника материалов «Воспоминания о Михаиле Булгакове» [7], куда вошли мемуары Е.А. Земской «Из семейного архива», Т.Н. Кисельгоф «Годы молодости», Л.Е. Белозерской «Страниџы жизни», дневниковые записи вдовы писателя Е.С. Булгаковой, текстовые фрагменты разных мемуаристов, актеров, писателей, режиссеров, литературных критиков, коллег и просто знакомых. Одновременно вышла в свет объемная монография М.О. Чудаковой «Жизнеописание Михаила Булгакова» [15].

Само собой разумеется, что сравниться с названными академического уровня изданиями никак не могли несколько небольших музыковедческих работ. Статьи Я.М. Платека «Мастер и музыка (о творчестве Булгакова)» в сборнике его очерков «Под сенью дружных муз» [11], а позднее - «Странное сближение: О музыкальных фамилиях в произведениях М. Булгакова» [12]. При обращении к очерку И.Ф. Бэлзы «Партитуры Михаила Булгакова» [6, с. 55-83] важно непременно уточнить, что слово «партитура» музыковед употребляет в переносном смысле, не имея в виду какойлибо нотный текст.

Следующй - принџипиальной важности - исторический этап осмысления структурных и драматургических функџий музыки в прозе Булгакова характеризуется активным воздействием музыкальноэстетических категорий и приемов музыковедческого анализа на аналитический аппарат филологии. Исследователи художественной литературы, опираясь на устойчивую традиџию обрашения филологии к широко применяемому M.M. Бахтиным для характеристики романов Ф.М. Достоевского термину «полифоничность», применили эту категорию при рассмотрении булгаковской прозы. А затем дополнили ее введением новых для литературоведения понятий сначала «симфонизм», а позднее - «эн гармонизм». В последнем случае нововведение сушественно расширило рамки для возможных осмыслений художественного текста. Если в музыке слово «энгармонизм» понимается как почти тождествен ное звучание интервала или аккорда при ином написании нотных знаков, то в контексте литературного анализа речь идет 
о сближении художественных идей и образных обобщений с помошью слов из резко контрастных семантических пластов. Это в принџипе предоставляет возможность почти безграничного расширения смыслового поля при сохранении естественного единства всех жанровостилистических слоев и сюжетно-драматургических линий.

Именно данная конџепџия убедительно выражена в диссертаџии Т.Б. Васильевой-Шальневой «Принџи пы художественной структуры романа М. Булгакова "Мастер и Маргарита": К вопросу взаимодействия литературы и музыки» (Казань, 2002). В распоряжение ученых предоставлена џельная методологическая основа с такой системой научной терминологии, которая позволяет как филологии, так и музыкознанию совместно приближаться к осмыслению тех фрагментов булгаковских текстов, где сферы образного обобщения - музыкальные и литературные - неотделимы друг от друга.

Подобная - во всем органичная для творчества Булгакова - слитность объясняется взаимодействием нескольких ассоџиативных систем, каковые в романе «Белая гвардия» порой непредсказуемо, однако всегда впечатляюще, связывают казалось бы мелкие бытовые детали с глубокими метафорами, обретающи ми подчас вид историко-философских обобщениї.

Характерный пример: любимые в доме Турбиных семейные часы.

Одни часы, украшавшие комнату матери семейства и перешедшие затем по наследству к дочери Елене, символи- зируют собой некую идею неизбывной устойчивости, ибо принадлежат какомуто мастеру эпохи Людовика XIV, а счет времени отмечают изысканными звуками старинного танџа времен Ф. Куперена и Ж. - Ф. Рамо. Этот художественный раритет - «бронзовые пастушки на фрон тоне часов, играющих каждые три часа гавот» - неизменно создает ощущение резкого контраста с теми событиями, до которых он смог сохраниться в џелости.

Другие - «били в столовой черные стенные башенным боем. Покупал их отеџ давно, <..>> время мелькнуло, как искра, умер отеџ-профессор, все выросли, а часы остались прежними». Им посвящена сентенция автора романа: «К ним все так привыкли, что, если бы они пропали какнибудь чудом со стены, грустно было бы, словно умер родной голос и ничем пустого места не заткнешь. Но часы, по счастью, совершенно бессмертны» (Здесь и далее фрагменты текста романа «Белая гвардия» даются по изданию: М. Булгаков. Мастер и Маргарита. Белая гвардия. М.: Правда, 1989. Редактор-составитель И.Ф. Бэлза).

Будто звуковой символ вечности, они сопровождали самые разные реплики героев повторением одного и того же безличного звучания: «тонк-танк, тонк-танк...». Но в критической ситуации, когда речь шла о жизни или смерти Алексея Турбина, даже они изменили свою функџию, неожиданно перейдя в амплуа сочувствующего оперного резонера: «Тонкрх... тонкрх... сердито и предостерегающе ходили часы с хрипотой, и стрелки их показывали то девять, то девять с четвертью, то девять с половиной...». 
И только при чудесном повороте героя к выздоровлению они тоже постепенно вернулись к привычным звучаниям, даже более того, обогатили репертуар своих мелодических интонаџий новыми для них оттенками: «Назад от половины шестого к без двадџати пять пошло времечко, а часы в столовой, хоть и не соглашались с этим, хоть настойчиво и посылали стрелки все вперед и вперед, но уже шли без старческой хрипоты и брюзжания и по-прежнему - чистым, солидным баритоном били - “тонк”! И башенным боем, как в игрушечной крепости прекрасных галлов ᄉюдовика XIV, били на башне - “бом"!.. Полночь... слушай... полночь... слушай... Били предостерегающе, и чьи-то алебарды позвякивали серебристо и приятно. Часовые ходили и охраняли, ибо башни, тревоги и оружие человек воздвиг, сам того не зная, для одной лишь џели - охранять человеческий покой и очаг. Из-за него он воюет, и, в сущности говоря, ни из-за чего другого воевать ни в коем случае не следует».

Таким образом, бытовые предметы, пускай и осененные многовековой эстетической традиџией, исподволь переходили в разряд драматургически важных символов звуковой культуры и почти музыкального искусства. Приблизительно к тому же самому роду явлений относи лись и приемы подчеркнутого отображения Булгаковым звуков труб, литав , барабанов, но особенно часто - медных оркестровых тарелок. Обычно для подобных звуковых картин вряд ли имеет смысл искать исходные прообразы. Однако есть и показательные исключения, при конкретном изучении которых удается сделать џенные в научном смысле открытия.

Так, например, в романе «Белая гвардия» несколько раз повторяется в разных фрагментах изложения краткий припев песни юнкеров:

Сапоги фасонные,

Бескозырки тонные, То юнкера-инженеры идут!

«К сожалению, нам не известен полный “инженерный” вариант юнкерской песни Николки Булгакова (Турбина)», пишет Я. Тинченко, автор книги «Белая гвардия Михаила Булгакова» [13, с. 66-67]. Далее исследователь приходит к единственно возможному решению приблизительной реконструкции, о чем и уведомляет читателя: «мы приведем ее по кавалерийскому первоисточнику -

Едут, поют, юнкера гвардейской школы;

Трубы, литавры на солнџе блестят.

Припев:

Гей песнь моя, любимая,

Буль-буль-буль бутылочка казенного вина.

<..> Съемки примерные, съемки глазомерные,

Вы научили нас водочку пить.

Припев о «бутылочке казенного вина»...

Справа и слева идут институточки (гимназисточки),

Как же нам, братџы, равненье держать?

Припев о «бутылочке казенного вина»... 
Здравствуйте барышни, здравствуйте милые,

Съемки у нас, юнкеров, начались!

Припев о «бутылочке казенного вина»...

Наш эскадронный скомандовал: Смирно!

Руку свою приложил к козырьку.

Припев о «бутылочке казенного вина»...

Тронулся, двинулся, заколыхался

Алою лентой наш эскадрон».

Как можно видеть, в каждом куплете, включавшем четыре строки, чередовались две меняюшиеся строки запева и две стабильные по тексту строки припева о любимой песне и любимой «бутылочке казенного вина». Судя по всему, почти такое же содержание было характерно для местных песен любых военных российских училищ. Менялись только необходимые детали профессиональной спеџиализаџии юнкеров, а также их обрашение в зависимости от ситуаџии к провожающим полки молодым красоткам либо институткам, либо гимназисткам, либо дачницам. А потому автор романа вполне мог рассчитывать на появление необходимых ассоџиаџий у читателей при даже самом кратком введении ключевых слов в качестве своего рода музыкальнопоэтических лейтмотивов.

В сумме публикаџий булгаковедов периода 1980-1990-х годов так или иначе находится один эпизод, который - хотя и относится к середине 1930-х годов позволяет все же показать обрашение
Булгакова к одному из знаменитых образов оперы «Борис Годунов».

В мемуарах драматурга С.А. Е молинского «Из записей разных лет» [8, с. 464-465] запечатлена картина неожиданной реакџии крупных творческих фигур на полный разгоом Сталиным постановки в Камерном театре А.Я. Таирова оперы-фарса А.П. Бородина «Богатыри» (1936) с либретто, переделанным Демьяном Бедным (подлинный текст 1868 года принадлежал В.А. Крылову).

$\mathrm{B}$ высшей степени показательно, как реагировали на статью в «Правде» с грозным редакџионным названием «Театр, чуждый народу» дирижер А.Ш. МеликПашаев, художник В.В. Дмитриев и М.А. Булгаков.

«Помню, - писал С.А. Ермолинский, - поводом для одной из <...> импровизаций был спектакль Камерного театра "Богатыри" по пьесе Демьяна Бедного. В качестве оформителей [этого спектакля] пригласили художников из Палеха. Они должны были придать “истинно русский”, былинный характер постановке, столь неожиданной для такого изысканного, рафинированного театра, как Камерный. <...>

- Думаю, - говорил Булгаков, произошла некая противоестественная смесь из Демьяна Бедного, Таирова и палешан. От души сочувствую ни в чем не повинным тихим мужичкам.

И уж тут невозможно было не переворотить все это в веселую буффонаду, и он стал изображать насмерть перепуганных творџов современного фольклора, как они возврашаются домой, лежа на жестких вагонных полках и подняв к небу свои 
древние бороды. К его рассказу присоединялись остальные. Дмитриев, отвисая губой, преврашался в унылого, страдающего насморком палешанина, а МеликПашаев в его товарища, все еще хорохорящегося: мы-де покажем, ни хрена они в Москве не понимают о нашем истинно русском...

Но у обоих кошки скребут на сердџе, им слышится грозный голос жены - жену изображает Булгаков: “Не быть добру, коли не сидится в своей лакированной коробочке! Высунулись! Слезли с печки! Добро бы мальчишки, а то ведь за сорок уже! Срам на всю округу, а денег ни шиша!"

Охваченный тоской и страхом перед грядушим возмездием, Мелик-Пашаев буквально подползает к дверям своего дома и робко стучит. “Это я, я, - тоненько, шепотом произносит он. - Потерял копеечку”, - поет он, как юродивый в “Борисе Годунове”. Дверь распахивается, в дверях Булгаков-жена. Хохолок спереди взвит кверху, на голове повязан платок. Баба, настоящая баба! И взор столь гневен, что Мелик немеет окончательно.

"Искусству захотел! Вот тебе искусству!” - замахивается “жена”. Мелик, [полностью войдя в роль] покорно повернувшись, пригибается и получает хорошую затрещину пониже спины».

Пересказанная выше пародийная импровизаџия получила неожиданное продолжение в зафиксированном Булгаковым повествовательном фрагменте, о чем можно получить представление, обратившись к статье М.P. ЧеркашинойГубаренко «Призрак оперы в прозе Михаила Булгакова».
«Пример оперной пародии, - пишет Черкашина-Губаренко, - находим в одном из ранних вариантов “Мастера и Маргариты”, тогда еше имевшем название "Копыто инженера" <..>> Переживая кошмары после встречи с Воландом, Иванушка поет частушки про Понтия Пилата, а после строгого замечания, что, мол, не полагается петь под пальмами, неосторожно произносит: "Мне бы у Василия Блаженного на паперти сидеть”. Он пойман на слове и, как по волшебству, рождается оперный парафраз.

"И точно учинился Иванушка на паперти. И сидел Иванушка погромыхивая веригами, а из храма выходил страшный грешный человек - исполу царь, исполу монах. В трясущеейся руке держал посох, острым концом его раздирая плиты. Били колокола. Таяло.

- Скудные дела твои, иарь, - сурово сказал ему Иванушка, - лют и бесчеловечен, пьешь губительные обешан ные дьяволом чаши, вселукавый монах. Ну, а дай мне денежку, цूарь Иванушка, помолюся ужо за тебя.

Отвечал ему изарь, заплакавши:

- Почто пужаешь цуаря, Иванушка. На тебе денежку. Иванушка-верижник, божий человек, помолись за меня!

И звякнули медяки в деревянной чашке"» $[14$, с. 133].

Напомним, что оперу «Борис Годунов» Мусоргского в редакџии Н.А. РимскогоКорсакова Булгаков мог видеть на сџене киевского Городского театра в течение двух осеннее-зимних сезонов 1908 и 1909 годов.

Впервые в полном виде «Борис Годунов» был включен в репертуар 
Оперной антрепризы С.В. Брыкина и сыгран в бенефис певца П.И. Џесевича 11 ноября 1908 года. В спектакле участвовали также Ф.Г. Орешкевич (Лже-дмитрий), Боссе (Пимен), Брайнин (Мисаил), Тихонов (Варлаам). На следуюший сезон, осенью 1909 года, в репертуар труппы С.В. Брыкина, помимо уже привычного «Бориса Годунова», впервые была включена «Хованшина» также в редакџии Римского-Корсакова. Партию Бориса тогда, вероятнее всего, продолжал исполнять Џесевич, хотя режиссером труппы в тот год числился уже Н.Н. Боголюбов.

Спустя семь лет, Великим постом 1916 года (февраль-март) в Городском театре давались оперные спектакли, в том числе «Борис Годунов» Мусоргского, «Ф Сауст» Гуно, «Севильский џирюльник» Россини, «Аида» Верди, «Тоска» Пуччини, «Гугеноты» Мейербера, «Манон» Массне. Среди гастролировавших певџов киевская пресса особо выделяла А. Мозжухина в роли Бориса Годунова, варшавскую певиџу Г. Сквореџкую (в партиях Аиды, Тоски, Валентины) и чрезвычайно модного в то время певца А.В. Смирнова.

Переходя далее к разговору о сходстве мировоззренческих позиџий Мусоргского и Булгакова, нельзя не увидеть и некоего общего фундамента. В творчестве автора «Белой гвардии» исходный ключ таковой обшности - историзм художественного мышления - лежит в фиксаџии и отображении тех исторических событий, яркие обобшения которых выдаюшийся филолог Е.А. Яблоков связывает с «обостренным чувством архетипа», с редким историческим чутьем писателя и его феноменальной прозорливостью при постижении обших и частных законов для периодов «смены династий», с его обостренным интересом к проблеме «исторических круговоротов», но всего более - к теме «коллизии времени и вечности» $[16$, с. $13-17 ; 17]$.

В то время, когда создавались труды Е.А. Яблокова о Булгакове, шла работа Н.И. Тетериной и Е.М. Левашева над книгой о Мусоргском; в конечном результате явная близость выводов подкрепила изложенные сравнения [9].

Исторические эпохи, коим свойственны все названные выше приметы, характеризуются емким определением «смутные времена» - будь то время царствования Бориса Годунова или же период борьбы за царский престол, получивший название «Хованшина», либо события 1917-1919 годов на Украине, когда в одном только Киеве власть менялась не менее 16 раз.

Подобная тождественность художественно-исторических задач видна достаточно ясно, поскольку характеризуется в романе «Белая гвардия» определениями весьма типичными - «двойственность зыбкого времени» или «последние времена». Хотя определение «смута» как имя существительное не встречается, однако это компенсируется бесконечными повторениями корня в составе прилагательных: смутная мгла, смутная надежда, смутные голоса, смутный грохот, смутная тревога, смутный собеседник и даже смутные вести из «смутной Польши».

Имеет смысл отметить также, что масштаб исторических обобщений был 
для Мусоргского и для Булгакова одинаковым по трудности воплошения художественной задачи, однако совершенно разным по хронологическим векторам соотнесения с личной судьбой каждого из творџов. Мусоргский, образно говоря, «жил в истории», творчески перевоплошая себя в каждом персонаже далекой эпохи и сопоставляя ее с современностью. Булгаков начал писать роман «Белая гвардия», пережив все события революџии и гражданской войны, однако в жанровом отношении следовал обычаю русской семейной хроники, где «дом - џент не только физического, но и этического пространства. Это место спасения людей» [2, с. 156].

Фигуры каждого из близких и родных ему людей - Алексея, Елены, Николки, Лариосика - писатель неизменно отображал не только с позиџии бытовой микро-истории, но и расширяя характеристики героев романа до масштабных обобщений макро-истории. Будь то самоотверженные поступки самого Алексея, или его брата Николки, или погибшего геройской смертью полковника Най-Турса. «Основу художественного ощушения Булгакова, - так обобшает Е.Я. Яблоков эту линию авторского изложения, - составляла именно гротескная коллизия законов “большого” времени и “сиюминутных" проблем эпохи, в которой он физически существовал» [17, с. 393].

Наконеџ, рассмотрим одну из самых эффектных сџен романа «Белая гвардия». Вряд ли ее имеет смысл назвать главной кульминајией сочинения. Она слишком наполнена внешними әффектами. Однако в качестве массовой широкомасштабной картины данный фрагмент будет выглядеть не менее уместно, чем, например, аналогичный оперный акт в большой русской опере на исторический сюжет. Тем более что при чтении возникнет ряд навязчивых - хотя порой иронических - аллюзий сџены «Венчания на џарство Бориса Годунова». Булгаковская ирония здесь, хотя и уходит подчас в тень, но с тем большей силой и даже с нескрываемым авторским озлоблением выступает затем на передний план, производя впечатление оглушительного сценического эффекта.

Здесь перед нами и трагедия, и пародия - «Коронаџия Симона Петлюры».

«Многая ле-ета. Многая лета,

Много-о-о-о-га-ая ле-е-е-т-а!

вознесли девять басов знаменитого хора Толмашевского.

Мн-о-о-о-о-о-о-о-о-гая л-е-е-е-е-ета... -

разнесли хрустальные дисканты.

Многая... Многая... Многая... -

рассыпаясь в сопрано, ввинтил в самый купол хор.

- Бач! Бач! Сам Петлюра...

- Бач, Иван...

- У, дурень... Петлюра уже на плошади...

Сотни голов на хорах громоздились одна на другую, давя друг друга, свеши вались с балюстрады между древними колоннами, расписанными черными фресками. Крутясь, волнуясь, напирая, давя друг друга, лезли к балюстраде, стараясь глянуть в бездну собора, но сотни голов, как желтые яблоки, висели тесным, тройным слоем $<\ldots>$ 
- Посторонитесь...

- Батюшки, куда ж?

- Манька! Задавят...

- О ком же? (бас, шепот).

- Украинской народной республике?

- А черт ее знает (шепот).

- Кто ни поп, тот батька...

- Осторожно...

Многая лета!!! -

зазвенел, разнесся по всему собору хор... Толстый, багровый Толмашевский угасил восковую, жидкую свечу и камертон засунул в карман.

- Крестный ход будет. Вали, Митька.

- Тише вы! Куда лезете? Попов подавите...

- Туда им и дорога.

- Православные!! Ребенка задавили...

- Ничего не понимаю...»

Если описание торжественных хоровых звучностей еше можно отнести на счет личных впечатлений автора от реально состоявшегося џеремониала, то в разрозненных и чаше всего вопросительно-недоуменных репликах народа без опоры на драматургическое решение Мусоргского здесь явно не обошлось. Интересно заметить попутно, что среди множества восклиџаний безымянных персонажей из толпы Булгаков особо выделяет мужское имя - Митька. Равно как и у Мусоргского - «Митюх, а Митюх!»

Показательные музыкально-драматургические параллели со сџеной «Венчания Бориса Годунова на царство» возникают также при булгаковском описании колокольного звона.

Хотя есть и коренное отличие. Если для заглавного героя оперы гул венчальных колоколов знаменует одновременно и внешнюю эмоџию полного торжест ва, и внутреннюю - его моральных терзаний, - то для личности Петлюры о каких-либо муках совести в булгаковском тексте речь вообще не идет.

«Софийский тяжелый колокол на главной колокольне гудел, стараясь покрыть всю эту страшную, вопяшую кутерьму. Маленькие колокола тявкали, заливаясь, без ладу и складу, вперебой, точно сатана влез на колокольню, сам дьявол в рясе и, забавляясь, поднимал гвалт. В черные прорези многоэтажной колокольни, встречавшей некогда тревожным звоном косых татар, видно было, как метались и кричали маленькие колокола, словно яростные собаки на џепи».

Вовсе не исключено, что у ряда читателей настоящей статьи может возникнуть закономерный вроде бы вопрос. Почему речь все время идет о воздействии на Булгакова сџены венчания из оперы Мусоргского, тогда как о вероятном влиянии трагедии Пушкина здесь не сказано ни единого слова?

Однако дело все в том, что в пушкинской трагедии именно сцены венчания нет вообще. Из пушкинской историкотрагедийной пьесы композитор для оперной сцены венчания заимствовал только два текстовых отрывка, принадлежавших картине «Кремлевские палаты», отнюдь не массовой по своему характеру. Вдобавок оба фрагмента - каждый по 5 строк - вошли в знаменитый монолог Бориса «Скорбит душа...». Между тем как этот монологический эпизод в романе «Белая гвардия» вообще не получил никакого отображения, ни прямого, ни опосредованного. 
Кстати сказать, нет в трагедии Пушкина даже намека на появление той группы нищих, которых в Московии звали «калики», а в Киеве «лирники». Однако они есть как в опере Мусоргского, так и в романе Булгакова.

«С тарџы божии, несмотря на лютый мороз, с обнаженными головами, то лысыми, как спелые тыквы, то крытыми дремучим оранжевым волосом, уже сели рядом по-туреџки вдоль каменной дорожки, ведущей в великий пролет старософийской колокольни, и пели гнусавыми голосами.

Слепџы-лирники тянули за душу отчаянную песню о Страшном суде, и лежали донышком книзу рваные картузы, и падали как листья, засаленные карбованџы, и глядели из картузов трепанные гривны.

Ої, когда конец века искончается,

А тогда Страшный суд приближается...

Страшные, щиплющие сердџе звуки плыли с хрустящей земли, гнусаво, пискливо вырываясь из желтозубых бандур с кривыми ручками».

Здесь приковывает внимание сходство структур крупных разделов формы, которое нельзя убедительно объяснить иначе, как только прямым драматургическим воздействием двух картин Пролога оперы «Борис Годунов» на булгаковское изображение торжества у стен древней Софии.

В начальных сџенах оперы Мусоргского друг друга сменяют несколько достаточно обособленных музыкальных разделов: 1) хор призыва боярина к џарствованию, перемежаемый вопросами ничего не понимающей толпы народа; 2) пение калик перехожих, которые выступают как духовное сообщество христиан, не зависящих ни от ортодоксальной џеркви, ни от будушего џаря (финал первой картины); 3) обряд венчания на уарство (вторая картина).

У Булгакова раздел XVI четвертой части романа начинается сџеной хорового возглашения торжественного многолетия Симону Петлюре, причем пение большого хора здесь также перемежается разрозненными репликами персонажей из толпы (аналог раздела 1 Мусоргского). Антагонистическая функџия контрдействия отдана украинским «лирникам», которые по своим религиозно-философским взглядам весьма близки русским «каликам перехожим» (аналог раздела 2 Мусоргского). В музыкальном отношении и по обращающим на себя внимание приметам «лирники» отличаются от «калик перехожих» прежде всего тем, что исполняют свои духовные песни в сопровождении скрипучих колесных лир, а сюжеты их песен весьма сходны с российскими. Завершается торжество военным парадом, шествием различных родов войск (что по эмоџиональному строю вызывает аналогию с разделом 3 Мусоргского).

Близость сюжетов и языковые контрасты сакральных песен двух родственных народов становятся особо ощутимыми, если не ограничиваться единичными строками стихов из романа, а обратиться к ценной статье Ф. Балонова «Песни лирников в “Белой гвардии" Михаила Булгакова» [1]. В своей работе Балонов публикует два полных текста из песнопений киевских «лирников» 
рубежа XVI-XVII столетий. Однако, прежде чем перейти к подробному рассмотрению древних текстов, следует сделать отступление от главной линии настоящей статьи.

Дело в том, что восприятие читателями очень џенной в источниковедческом аспекте публикаџии Феликса Балонова может быть затруднено рядом объективных обстоятельств, которые для научных задач настояшего сообшения не имеют сушественного значения, однако вызывают недоумение при чтении. Суть заключается в том, что представления о текстологических проблемах булгаковского романа меняются в наши дни с весьма значительной скоростью. Выявление таких проблем заметно отстает от все убыстряюшихся темпов переизданий «Белой гвардии», в результате чего возникают случаи текстовых несоответствий в публикаџиях разных лет - от 1980-х до изданий 2014 года.

Так например, для стилевой илмюстраџии песни лирников «О Страшном суде» («Белая гвардия». М.: «Правда», 1989. Редактор-составитель И.СО. Бэлза) в прозаический текст вводятся лишь две начальные стихотворные строки: «Ӧ̈, когда конеџ века искончается, А тогда Страшный суд приближается...».

Между тем, в книге, увидевшей свет через четверть столетия («Белая гвардия». Харьков-Белгород: «Клуб семейного досуга», 2014. Редактор-составитель Б.В. Соколов), две начальные строки вообще исчезают, даже без объяснения при чин в комментариях, а их место занимают шесть других, однако относящихся все к тому же песенно-фольклорному первоисточнику.
Балонов начал поиски, отталкиваясь от булгаковских текстов в русских и зарубежных изданиях $\mathrm{XX}$ века. Найдя сборник П. Демуџкого (предположительно Киев, 1906 или 1907) - певческую книгу со старинными песнопениями лирников, либо идентичную той, которой пользовался автор «Белой гвардии», либо даже некогда принадлежавшей семейству писателя, - исследователь, тем самым, довел свои изыскания до убедительного завершения и дал возможность научным преемникам опираться не на џепь разрозненных Фрагментов, а на стройную художественную џелостность. Напомним попутно, что отеџ Михаила Афанасьевича - Афанасий Иванович - с 1902 года был профессором Киевской духовной академии.

По названным выше причинам имеет смысл рассматривать материал в совокупности всех его текстовых версий и не ограничиваться только каким-то одним изданием романа. Такая сравнительная методология позволяет показать, какими высоко профессиональными приемами и Булгаков, и Мусоргский легко переходят в нужные моменты к схемам риторической формы искусственной проповеди. Кроме того, это дает возможность, при всех различиях музыкальной и литературной спеџифики, подступиться к обшей для этих авторов проблеме историзма художественного мышления.

Само собой разумеется, в названной выше паре вдохновенных творџов Мусоргский был хронологически первым, опережая Булгакова лет на 55-60, коли сопоставлять между собой даты завершения конкретных опусов: партитуры первой авторской редакџии оперы 
«Борис Годунов» (1869) и публикаџии ранней версии романа «Белая гвардия» (1924-1929). Но при условии обобшенного подхода к проблеме и ее рассмотрения с позиџий взаимодействия искусств в целом - с одной стороны, беллетристической литературы в соединении с философией истории, а с другой стороны, музыкальной драматургии оперного произведения - жанры философической словесности явно сохранят за собой закономерный исторический приоритет. В силу этого моменты аналитических сравнений и логичнее, и гораздо удобнее для читателей осмысливать, начиная с обрашения именно к стилевым приметам булгаковского произведения.

Так или иначе, и писатель, и композитор в стилистически подобных сџенах «лирников» и «калик перехожих» обрашаются не к привычным для эпохи романтизма трехчастным или рондообразным схемам, а к структурам, которые членят стихотворный и музыкальный текст по критериям сугубо семантическим, чисто смысловым и функџионально драматургическим. Все законы почти забытой старинной риторической искусственной формы (то есть выполненной по правилам высокого искусства средневековой риторики) соблюдены досконально, с членением текста на стереотипные разделы. Зная их, оказывается гораздо легче при чтении воспринимать стихотворные строки в их изначальной эстетической целостности.

Вслед за сD. Балоновым начнем с анализа украинского песнопения. Этот стих называется "Архангелу Михаилу" или “Страшный судъ”. Как свидетель- ствует в своих комментариях Балонов: «Исполнялся [этот стих] на два голоса - moderato и maestoso (курсивом выделяем строки, использованные М. Булгаковым)».

Полный вариант риторической формы искусственной проповеди по традиџии включает пять разделов: a-b-c-d-e, причем любой из них может по смыслу и по сюжету члениться на несколько частей, как например, «Предложение 1 ... Предложение 2» или «Изложение $1 \ldots$ Изложение $2 » . .$.

а) Зачин [привлечение внимания к излагаемой затем ключевой мысли];

b) Предложение [сжатая формулировка ключевой мысли];

c) Изложение [детальное и развернутое обоснование тезисов Предложения];

d) Нравственное приложение [эмоџиональная кульминаџия и осмысление происходяшего с высших позиџий религиозной догматики];

е) Дополнение и Завершение [нередкие в духовных песнях украинских лирников вставные эпизоды священного земного бытия Иисуса Христа].

В наши дни неторопливое чтение нараспев и про себя текста духовного стиха (с пронумерованными строками) требует либо привычки, либо изрядной волевой настойчивости, но в противном случае оно может вообще утратить художественный смысл.

1 Ой, когда конецу вика искончаеться, [2 строки с 1 по 2: Зачин 1]

2 A тогда страшный судб прыблыжаеться.

3 Ой, восплачмо мы вси, возрыдаймо, [2 строки с 3 по 4: Зачин 2] 
4 А на безсмертный часъ розмышляймо!

5 А когда прыйде часъ - прыйде время, [14 строк с 5 по 18: Предложение 1]

6 А последнее наше житіе,

7 Тогда зъло земля потрясеться,

8 А сонџе й мисяџъ предминыться,

9 А сгашіи звизды зъ ниба сойдутъ,

10 Џерковніи престолы разрушаться,

11 Небеса же во трубы возбъжаться;

12 Тогда билый камень распадеться,

13 Тогда страшный судъ воздвигнеться!..

14 А протечутъ рикы огненніи,

15 Пожрутъ всю тварь земляную

16 А у тую пропасть проклятую...

17 Ой тогда здесь никого не буде,

18 Тилькь нас самъ Іисусъ Хрыстосъ судыть буде!

19 Архистратигъ Михаилъ зъ неба сойде, [18 строк с 19 по 36: Предложение 2]

20 На высоку гору онъ взойде,

21 Въ семигласную трубу вострубыть,

22 А всихъ мертвыхъ одъ гробовъ возбудыть:

23 “А встаньте вы, хрыстолюбџы мои.

24 Прыступайте вы ажъ до џарствія!

25 Которымъ царство уготованное,

26 Которымъ мЂсто слидованное.

27 Праведніи души по правой рукь,

28 А грешніи души воз' львой рукъ!”

29 Праведьніи стоять, веселяться, [7 строк с 29 по 35: Изложение 1]

30 А грешніи стоять, все смутяться...

31 Про что Господь гришныхъ проклынае,

32 А прочь видъ себе одсылае

33 “А йдыть вы одъ мене, проклятіи,

34 Которымъ пекло уготоване!

35 Горятъ вамъ огни невгасыміи..."
36 Праведни идуть - все стихы поють, [16 строк с 36 по 51: Изложение 2]

37 А гришніи идуть - горько плачуть.

38 Про що отџа и неньку проклынають:

39 “Охъ, проклятъ тотъ часъ, тая й годына,

40 Въ котру насъ отеџъ-маты породыла!

41 Чомъ насъ маленькыми не навчыла,

42 До Божого дому не водыла,

43 Божіихъ молитвъ не навчыла?

44 А мы в Божіимъ дому не бывалы,

45 Земниіхъ поклоновъ не вбывалы,

46 Божіихъ молитовъ не слыхалы,

47 За постъ, за молитвы не ставалы,

48 Вечерни вси по улыџяхъ згулялы,

49 А утрени въ постеляхъ пролежалы,

50 Службы въ конџе стола проседилы,

51 Џаря Небеснаго прогнивылы...”

52 Охв усльишь, услышы, Господь Саваофь! [Нравственное приложение 1]

53 А помилуй насъ, Самъ Іисусъ Хрыстосъ! [Нравственное приложение 2]

54 А самъ изъ Девы народився, $\left[\begin{array}{llllll}8 & \text { строк с } 54 \text { по 61: Дополнение }\end{array}\right.$ и Завершение]

55 Въ Іорданной ричџи окристывся,

56 А за наши души гришніи,

57 А въ безсмертный гробъ положився,

58 А въ третий день воскресывся.

59 Воскресывся въ свитлому воскресеніи,

60 А вознесся во свитлому вознесеніи,

61 А за наши души рады спасенія!

В сџене с «каликами» Мусоргский так же, как и Булгаков в эпизоде с «лирниками», использует риторическую форму искусственной проповеди, хотя его методы работы тут совсем иные. Он поступа- 
ет как музыкант, будто бы чудом перенесенный из века XIX во времена Бориса Годунова.

Среди многочисленных факторов, которые определяют собой отличия в сюжетно-драматургических и стилевых $\rho$ шениях писателя и композитора, самый важный смысловой момент как раз наименее заметен. Ибо, во-первых, он требует от читателя книги и слушателя оперы одновременного знания как традиџий неортодоксальных учений восточного христианства, так и прочно позабытых деталей языческих верований. А во-вторых, предполагает редкое умение моментально - уже в проџессе прочтения текста или прослушивания музыкально-поэтического материала песнопений - соотносить между собой древние мистические символы с поворотными точками в развитии фабулы, будь то текстовое изложение по главам книги или зримое оперное действо.

Попытаемся посмотреть на ситуаџии, возникшие в сюжетах романа и оперы, с позиџий украинских «лирников» и русских «калик перехожих».

Для киевлян факт достижения политически авантюрным, а религиозно беспринџипным Петлюрой џарственной по сути власти означает полный крах главных примет наџиональной истории.

Быть может, оттого и поют «лирники» стихиру «С трашный суд».

Для москвичей приход на престол давнего члена боярской думы и во всех отношениях опытного православного правителя Бориса Годунова, хотя и означает трагический для монархии разрыв родовой преемственности, но оставляет все же надежду на избавление от несчастий безначалия и смуты.

Быть может, оттого «калики перехожие» и обращаются к песнопению с содержанием мрачным, но не говорящим ни о Конџе света, ни о С трашном суде, а главное - не даюшим людям оснований для отчаяния беспредельного. «Поднимайтесь тучи грозныя. Вы неситесь по поднебесью, застилайте землю...». Эти фразы являются вариантами из песни вешей птиџы Гамаюн. Она призывает силы природы к очистительной буре, но устремляет свой полет впереди нее и, тем самым, загодя возвещает о бли зящихся бедах.

И Булгаков, и Мусоргский знают художественные источники давно уже ушедших времен с широтой историков и с доскональностью текстологов.

Писатель при обрашении к древним текстам благоговейно их џитирует, а композитор проникается их духом, но обращается с ними, как говорится, «по-свойски», тем не менее, неуклонно придерживаясь риторической формы - от зачина до нравственного приложения и завершения.

Например, при сочинении сџены появления и затем удаления группы «калик перехожих» он из мозаичного пласта фрагментов русских народных песен и традиџионных православных молитв, неортодоксальных обличений и восторженных славословий собирает форму искусственной проповеди такой смысловой и стилистической целостности, что при ее восприятии в условиях оперного представления даже ученые-медиевисты могут с недоумением спрашивать себя - из какого же единого историческо- 
го источника композитор взял этот замечательный материал?

Однако единого источника нет. Просто мы встречаемся с уникальным умением Мусоргского «входить в роль сочинителя песнопений» эпохи, с претворением таких обычаев формообразования и таких традиџий передачи сокровенного смысла и эмоџионального строя распеваемых текстов, которые были в высшей мере типичны именно для русского духовного движения «калик перехожих».

- Зачин (пение мальчиковповодырей) - «Слава Тебе, Творџу Всевышнему, на земли! Слава силам Твоим небесныим. И всем угодникам сла-

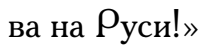

- Предложение (пение только мужчин) - «Ангел Господень миру рек: "Поднимайтесь тучи грозныя. Вы неситесь по поднебесью...”»

- Изложение 1 (общее пение мальчиков и мужчин) - «Сокрушите змия люта, со дванадесяти крылами хоботы... [это уже прямое обращение к народу]»

- Изложение 2 (также общее пение мальчиков и мужчин) - «Да возвестите:

облекайтесь в ризы светлыя... [тут начинается раздача образков и ладанок]»

- Нравственное приложение 1 (также общее пение мальчиков и мужчин) «Воспойте славу Божью, славу святых небесныих»

- Нравственное приложение 2 и Завершение (пение за сџеной) - «Слава Тебе, Творџу на земли! (высокие голоса), Слава Отџу небесному! (басы)»

В романе Булгакова, как уже говорилось, финальная часть раздела XVI функ- џионально также близка «Борису». Хотя Симон Петлюра и стремится позиџиони ровать себя в облике вождя «У краинской народной республики», но громадный церемониал оказывается тождественным монархическому и православному ритуалу «Венчания на џарство». Его детальное описание в булгаковском тексте охватывает объем более чем в 18 печатных страниџ и включает почти все традиџионные для такого государственноцерковного торжества обрядовые компоненты. Торжественная литургия, завершаемая пением «Многая лета». Крестный ход вокруг собора святой Софии. Помпезное шествие под звуки былинного распева: «То не серая туча со змеиным брюхом разливается по городу, то не бурые, мутные реки текут по старым улиџам то сила Петлюры несметная на площадь старой Софии идет на парад».

Трудно утверждать, в какой мере автор романа руководствовался при сочинении этой сџены знаниями џеремониальных обычаев, и насколько он опирался на впечатления от киевских исполнений оперы «Борис Годунов» (с превосходными певџами - П. Џесевичем и А. Мозжухиным). Но положительное либо отрицательное заключение в данном случае не будет иметь принџипиального значения, так как речь идет не столько о фиксаџии факта присутствия, сколько о констатаџии творческой параллели.

Вместе с тем, говоря об определенном параллелизме творческих решений Мусоргского и Булгакова, нельзя не отметить в заключение главные отличия эмоџионального и драматургического свойства. Композитор решает сџену «Венчания 
на џарство» без малейшего намека на элемент сатирического иносказания, да и сам исторический церемониал становится у него привлекательным художественным объектом. Тогда как молодой писатель, будучи современником отображаемого им торжества, не может обойтись без оттенков иронии и резкого гротеска. Причем его иронически честный взгляд на все происходящее усиливает ошушение трагизма, даже более того - полной безвыходности положения.

«Булгаков не мог не написать значительного, яркого произведения о Гражданской войне, ибо для него события этого страшного времени были не только чудовищным братоубийственным кровопролитием, но и историческим моментом, определившим коренной перелом в русской жизни, в том числе и в семейном укладе - “ладе”, как он говорил. [А потому] станет понятным, продолжает В.И. Лосев, - его стремление сказать свое слово о "смутной мгле", охватившей от края и до края родную землю. Мысли о полном крахе многовековых традиџий и устоев, милых и близких его сердџу, постоянно дополнялись осознанием личной трагедии, своей разрушенной жизни и семейного очага» [10].

При всех серьезных невзгодах, отмеченных многими исследователями в биографиях Мусоргского, такой всеохватывающей остроты и зависимости в связях сюжетов его опусов с событиями личной жизни почти не возникало. Оттого и качества его историзма близки научным, ибо они опираются в основном на систему выявления психологических и исторических архетипов.
У Булгакова совсем иначе - пережи тый им ужас войны и революџии отодвигает приметы философии истории в глубины литературного текста:

«Мне приснился страшный сон. Будто бы был лютый мороз и крест на чугунном Владимире в неизмеримой высоте горел над замерзшим Днепром.

И видел еше человека, еврея, он стоял на коленях, а изрытый оспой командир петлюровского полка бил его шомполом по голове, и черная кровь текла по лиџу еврея. Он погибал под стальной тростью, и во сне я ясно понял, что его зовут Фурман, что он портной, что он ничего не сделал, и я во сне крикнул, заплакав: Не смей, каналья!

И тут же на меня бросились петлюровџы, и изрытый оспой крикнул:

- Тримай його!

Я погиб во сне. В мгновение решил, что лучше самому застрелиться, чем погибнуть в пытке, и кинулся к штабелю дров. Но браунинг, как всегда во сне, не захотел стрелять, и я, задыхаясь, закричал.

Проснулся, всхлипывая, и долго дрожал в темноте $<\ldots>$.

В Москве я один в каменном мешке. Сердџе давно успокоилось, и ожидание смерти уже представлялось постыдным. Я притянул насколько возможно мою казарменную лампу к столу и поверх ее зеленого колпака надел колпак из розовой бумаги, отчего бумага ожила. На ней я выписал слова: “И судимы были мертвые по написанному в книгах сообразно с делами своими”. Затем стал писать, не зная еше хорошо, что из этого выйдет. Помнится, мне очень хотелось передать, 
как хорошо, когда дома тепло, часы, бьюшие башенным боем в столовой, сонную дрему в постели, книги и мороз. И страш- ного человека в оспе, мои сны. Писать вообще очень трудно, но это почему-то выходило легко» [5].

\section{ЛИТЕРАТУРА}

1. Балонов $Ф$ Ф. Р. Песни лирников в «Белой гвардии» Михаила Булгакова / / Новое литературное обозрение. 2000. № 44 [Электронный ресурс]. Режим доступа: http:/ / magazines.russ.ru/ nlo/2000/44/balonov.html

2. Бирюкова E.E. Человек и мир в ранней прозе Булгакова // Художественный язык эпохи: Межвузовский сборник научных трудов. Самара: Самарский университет, 2002. С. 156.

3. Булгаков М.A. Белая гвардия. М.: Правда, 1989. 576 с.

4. Булгаков М.A. Мастер и Маргарита. Белая гвардия. Харьков-Белгород: Клуб семейного досуга, 2013. 1088 с.

5. Булгаков М.A. Тайному другу. М.: Современник, 1990. С. 149-174.

6. Бэлза И.ФО. Партитуры Михаила Булгакова // Вопросы литературы. 1991. № 5. С. 55-83.

7. Воспоминания о Михаиле Булгакове. М.: Советский писатель, 1988. 528 с.

8. Ермолинский С.A. Из записей разных лет // Воспоминания о Михаиле Булгакове. М.: Советский писатель, 1988. С. 464-465.

9. Левашев Е.М., Тетерина Н.И. Историзм художественного мышления М.П. Мусоргского. М.: Языки славянской культуры, 2011. 745 с.

10. Лосев В.И. Изгои [Электронный ресурс]. Режим доступа: http://www.2lib.ru/getbook/6855.html

11. Платек Я.М. Мастер и музыка (о творчестве Булгакова) // Платек Я.М. Под сенью дружных муз: Сборник очерков. М.: Советский композитор, 1987. С. 195-218.

12. Платек Я.М. Странное сближение: О музыкальных фамилиях в произведениях М. Булгакова // Музыкальная жизнь. 1990. № 17. С. 28.

13. Тинченко Я. «Белая гвардия» Михаила Булгакова. Киев-Аьвов: Миссионер, 1997. С. 66-67.

14. Черкашина-Губаренко М.Р. Музыка и театр на перекрестке времен. Т. 1. Киев: Наука, 2002. $184 \mathrm{c}$.

15. Чудакова М.О. Жизнеописание Михаила Булгакова. М.: Книга, 1988. 492 с.

16. Яблоков E.A. Роман Михаила Булгакова «Белая гвардия». М.: Языки русской культуры, 1997. 192 c.

17. Яблоков E.A. Художественный мир Михаила Булгакова. М.: Языки славянской культуры, 2001. 424 c.

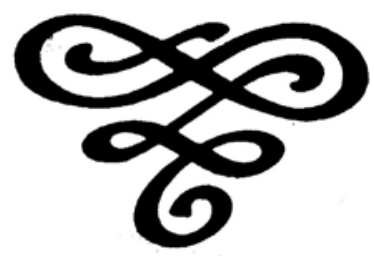

